Research Article

\title{
Formulation and Development of Fast Disintegrating Azelnidipine Tablets: Functionality of Superdisintegrants
}

\author{
S.K.Sathish ${ }^{1 *}$, Dr. V.P. Pandey² \\ ${ }^{1}$ Department of Pharmaceutics, Ultra College of Pharmacy, Madurai, Tamil Nadu, India. \\ ${ }^{2}$ Department of Pharmacy, Annamalai university, Annamalai nagar, Chidambaram, Tamil Nadu, India. \\ *Corresponding author's E-mail: krrs78@gmail.com
}

Received: 10-03-2021; Revised: 20-05-2021; Accepted: 28-05-2021; Published on: 15-06-2021.

\section{ABSTRACT}

Azelnidipine, a calcium channel blocker, is used for hypertension and angina pectoris. Azelnidipine fast-disintegrating tablets (FDT) have been prepared by kneading method. In the present study cyclodextrins ( $\beta C D$ and HPBCD) and surfactants (Kolliphor HS15) were tried to enhance the solubility and dissolution rate of Azelnidipine. The individual main effects and combined (interaction) effects of cyclodextrins and surfactants on the solubility and dissolution rate of Azelnidipine was evaluated in a series of 22 factorial experiments.) The hardness, friability, drug content and disintegration time, in vitro release and stability parameter has been studied. Hardness of the tablets was in the range $6.0-7.5 \mathrm{~kg} / \mathrm{sq} . \mathrm{cm}$. Percent weight loss in the friability test was less than $0.85 \%$ with all the formulations. The disintegration time was in the range $1-3.5 \mathrm{~min}$. with all the tablets prepared. Drug content of the tablets was within $100 \pm 2 \%$ of the labeled claim. The dissolution efficiency was also increased from $4.56 \%$ for formulation E1 to $41.54 \%$ and 36.59 $\%$ respectively for formulations E4 and E8. The formulation did not show any change in disintegration time and drug content after stability period. It was concluded that fast disintegrating Azelnidipine tablets can be prepared by kneading method using super disintegrants.

Keywords: Azelnidipine tablets, cyclodextrins, surfactants (Kolliphor HS15).

QUICK RESPONSE CODE $\rightarrow$

DOI:

10.47583/ijpsrr.2021.v68i02.017

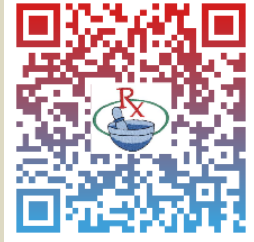

DOI link: $\underline{\text { http://dx.doi.org/10.47583/ijpsrr.2021.v68i02.017 }}$

\section{INTRODUCTION}

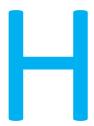

ypertension is the most common chronic disease and the calcium channel antagonist is the most popularly used antihypertensive drug. Azelnidipine is a third generation and long-acting dihydropyridine calcium channel antagonist ${ }^{1}$. A series of research has demonstrated that azelnidipine produced an effective antihypertensive effect in patients with essential hypertension. Solid dosage forms are popular because of ease of administration, accurate dosage, self-medication, pain avoidance and most importantly the patient compliance. The most popular solid dosage forms are being tablets and capsules, one important drawback of this dosage form for some patients is the difficulty to swallow ${ }^{2}$. Mouth dissolving tablets provide an advantage, particularly for pediatric and geriatric populations who have difficulty in swallowing conventional tablets and capsules. Mouth dissolving of tablet results in quick dissolution and rapid absorption, which provide rapid onset of action. Moreover, a drug candidate that undergoes pre-gastric absorption when formulated as mouth dissolving tablets may show increased oral bioavailability ${ }^{3}$. It provides good stability, accurate dosing, and easy manufacturing.

Azelnidipine is a vasodilator that induces a gradual decrease in blood pressure in hypertensive patients. Unlike other members of its drug class, azelnidipine does not induce reflex tachycardia due to vasodilation. This is likely due to the fact that it elicits a gradual fall in blood pressure. It also exhibits a prolonged hypotensive effect and has been shown to have a strong anti-arteriosclerotic action in vessels due to its high affinity for vascular tissue and antioxidative activity ${ }^{4}$. Clinical studies have demonstrated that azelnidipine markedly reduced heart rate and proteinuria in hypertensive patients by inhibiting sympathetic nerve activity. Azelnidipine has also been confirmed to have cardio-protective, neuroprotective, and anti-atherosclerotic properties, and has also been found to prevent insulin resistance ${ }^{5}$ Azelnidipine inhibits transmembrane $\mathrm{Ca} 2+$ influx through the voltage-dependent channels of smooth muscles in vascular walls. Ca2+ channels are classified into various categories, including Ltype, T-type, N-type, P/Q-type, and R-type Ca2+ channels. The L-type Ca2+ channels $\underline{6}$. Normally, calcium induces smooth muscle contraction, contributing to hypertension. When calcium channels are blocked, the vascular smooth muscle does not contract, resulting in relaxation of vascular smooth muscle walls and decreased blood pressure.

Mouth dissolving tablets are designed to be placed in mouth allowed to dissolve in the saliva and then swallowed without the aid of water ${ }^{7-9}$. The objective of the present 
investigation was to develop fast disintegrating. The major objective is to enhance the immediate onset of action in a shorter period of time with improved bioavailability, solubility, dissolution rate. Azelnidipine tablets to evaluate the individual main effects and combined (interaction) effects of cyclodextrins ( $\beta C D$ and $H P B C D$ ) and surfactants (Kolliphor HS15and Pluronic F127). A series of $2^{2}$ factorial experiments and to evaluate the feasibility of formulating Azelnidipine tablets with enhanced dissolution rate and dissolution efficiency employing drug-CD-surfactant complex systems.

\section{MATERIALS AND METHODS}

Azelnidipine was gifted sample from M/s Amoli Organics Pvt., Ltd., Mumbai. $\beta$-cyclodextrin and hydroxy propyl $\beta$ cyclodextrin were gift samples from Signet Chemical Corporation Pvt., Ltd., Mumbai. Pluronic F127(BDH), Kolliphor HS15(SD Fine Chem.). All other materials used were of Pharmacopoeial grade.

\section{Methods}

\section{Formulation of Tablets}

Employing Drug-CD-Kolliphor HS15 Complexes as per a $2^{2}-$ Factorial Study: Tablet of Azelnidipine (16mg) were formulated employing selected combinations of $C D$ ( $\beta C D$ and HPBCD ) and Kolliphor HS15in each case as per a $2^{2}-$ Factorial design. For this purpose 2 levels of $C D$ ( 0 and 1:2 ratios of drug : CD ) and two levels of Kolliphor HS15( 0 and $5 \%$ ) were selected and the corresponding four treatments involved in the $2^{2}$-Factorial study.

\section{Preparation of Tablets}

Tablet of Azelnidipine (16mg) were prepared by wet granulation method as per the formulae given in Tables 12.

\section{Azelnidipine Tablets with $\beta C D$ and Kolliphor HS15}

\begin{tabular}{|c|c|c|}
\hline $\begin{array}{c}\text { Statistical code as } \\
\text { per } 2^{2}-\text { Factorial } \\
\text { Design }\end{array}$ & Description & $\begin{array}{l}\text { Formulation } \\
\text { code }\end{array}$ \\
\hline 1 & $\begin{array}{c}\text { Tablets of } \\
\text { Azelnidipine alone }\end{array}$ & $\mathrm{A} 1$ \\
\hline a & $\begin{array}{l}\text { Tablets of } \\
\text { Azelnidipine }-\beta C D(1 \text { : } \\
\text { 2) inclusion complex }\end{array}$ & $A 2$ \\
\hline$b$ & $\begin{array}{c}\text { Tablets of } \\
\text { Azelnidipine - } \\
\text { Kolliphor HS15 (5\%) } \\
\text { blend }\end{array}$ & A3 \\
\hline$a b$ & $\begin{array}{c}\text { Tablets of } \\
\text { Azelnidipine } \beta C D- \\
\text { Kolliphor HS15 ( } 1: 2 \text { : } \\
0.05 \text { ) ternary } \\
\text { complexes }\end{array}$ & A4 \\
\hline
\end{tabular}

Azelnidipine Tablets with HPBCD and Kolliphor HS15

\begin{tabular}{|c|c|c|}
\hline $\begin{array}{l}\text { Statistical code } \\
\text { as per } 2^{2}- \\
\text { Factorial Design }\end{array}$ & Description & $\begin{array}{l}\text { Formulation } \\
\text { code }\end{array}$ \\
\hline 1 & $\begin{array}{c}\text { Tablets of Azelnidipine } \\
\text { alone }\end{array}$ & $\begin{array}{c}\text { A5 } \\
\text { Same as A1 }\end{array}$ \\
\hline$a$ & $\begin{array}{l}\text { Tablets of Azelnidipine - } \\
\text { HßCD }(1: 2) \text { inclusion } \\
\text { complex }\end{array}$ & A6 \\
\hline$b$ & $\begin{array}{l}\text { Tablets of Azelnidipine - } \\
\text { Kolliphor HS15( 5\% ) } \\
\text { blend }\end{array}$ & $\begin{array}{c}\text { A7 } \\
\text { Same as A3 }\end{array}$ \\
\hline$a b$ & $\begin{array}{l}\text { Tablets of Azelnidipine - } \\
\text { HBCD- Kolliphor HS15( } 1 \text { : } \\
2 \text { : } 0.05 \text { ) ternary } \\
\text { complexes }\end{array}$ & A8 \\
\hline
\end{tabular}

\section{Method}

Drug-CD-Kolliphor HS15ternary complex systems as per the formulae given in Tables $1-2$ were initially prepared in each case by kneading method. To the dried ternary complex in the mortar lactose and PVP were added and mixed thoroughly. Water-alcohol ( 1:1) solution was added and mixed thoroughly to form a dough mass. The mass was passed through mesh No. 12 to obtain wet granules. The wet granules were dried at $60^{\circ} \mathrm{C}$ for $4 \mathrm{hr}$. The dried granules were passed through mesh No. 16 to break the aggregates. Cross carmellose sodium, talc and magnesium stearate were passed through mesh No. 100 onto dry granules and blended in a polyethylene bag. The tablet granules were then compressed into tablets on a rotary multi-station tablet punching machine $(\mathrm{M} / \mathrm{s}$. Cadmach Machinery Co. Pvt. Ltd., Mumbai) to a hardness of $6-7 \mathrm{~kg} / \mathrm{sq} . \mathrm{cm}$ using $9 \mathrm{~mm}$ round and flat punches.

\section{Evaluation of Tablets}

All the tablets prepared are evaluated for

i) Content of active ingredient ii) Hardness iii) Friability iv)Disintegration time v) Dissolution rate

\section{Content of Active Ingredient}

Five tablets were accurately weighed and powdered. Tablet powder equivalent to $50 \mathrm{mg}$ of the medicament was taken into a boiling test tube and extracted with $4 \times 10 \mathrm{ml}$ quantities of methanol. The methanolic extracts were collected into $50 \mathrm{ml}$ volumetric flask and the volume was made up to $50 \mathrm{ml}$ with methanol. The solution was subsequently diluted with phosphate buffer of $\mathrm{pH} 6.8$ in the case of Azelnidipine.

\section{Hardness}

Hardness of the tablets was tested using a Monsanto hardness tester.

\section{Friability}

Friability of the tablets was determined in a Roche friabilator. 


\section{Disintegration Time}

Disintegration times were determined in thermonic tablet disintegration test machine using distilled water as fluid.

\section{Dissolution Rate Study}

The dissolution rate of medicament from the tablets prepared was studied in phosphate buffer of pH 6.8 (900 $\mathrm{ml}$ ) in the case of Azelnidipine tablets using Dissolution 2000 (Labindia) 8-station dissolution test apparatus with a paddle stirrer at $50 \mathrm{rpm}$. A temperature of $37^{\circ} \mathrm{C} \pm 1^{\circ} \mathrm{C}$ was maintained throughout the study. One tablet was used in each test. Sample of dissolution media $(5 \mathrm{ml})$ were withdrawn through a filter $(0.45 \mu)$ at different intervals of time, suitably diluted and assayed for Azelnidipine tablets at $250 \mathrm{~nm}$. The sample of dissolution fluid withdrawn at each time was replaced with fresh fluid and a suitable correction was made for the amount of drug lost in the samples in calculating the percent drug dissolved. The dissolution experiments were replicated four times each $(n=4)$.

Table 1: Formulae of Azelnidipine Tablets Prepared Employing $\beta C D$ and Kolliphor HS15as per $2^{2}$ Factorial Design

\begin{tabular}{|c|c|c|c|c|}
\hline Ingredient $(\mathbf{m g} / \mathrm{tab})$ & \multicolumn{4}{|c|}{ FORMULATION } \\
\hline Azelnidipine & $\mathbf{A 1}\left(\mathbf{F}_{\mathbf{1}}\right)$ & $\mathbf{A 2}\left(\mathbf{F}_{\mathbf{a}}\right)$ & $\mathbf{A 3}\left(\mathbf{F}_{\mathbf{b}}\right)$ & $\mathbf{A 4}\left(\mathbf{F}_{\mathbf{a b}}\right)$ \\
\hline BCD & 16 & 16 & 16 & 16 \\
\hline Kolliphor HS15 & - & 31.6 & - & 32 \\
\hline Croscarmellose Sodium & - & - & 1 & 1 \\
\hline PVP & 10.3 & 10.3 & 10.3 & 10.3 \\
\hline Talc & 2.5 & 2.5 & 2.5 & 2.5 \\
\hline Magnesium stearate & 2.5 & 2.5 & 2.5 & 2.5 \\
\hline Lactose & 2.5 & 2.5 & 2.5 & 2.5 \\
\hline Total weight (mg) & 42.5 & 10.9 & 41.5 & 9.5 \\
\hline
\end{tabular}

Table 2: Formulae of Azelnidipine Tablets Prepared Employing HPßCD and Kolliphor HS15as per $2^{2}$ Factorial Design

\begin{tabular}{|c|c|c|c|c|}
\hline \multirow{2}{*}{ Ingredient (mg/tab) } & \multicolumn{4}{|c|}{ FORMULATION } \\
\hline & $\mathrm{A} 1\left(\mathrm{~F}_{1}\right)$ & $A 2\left(F_{a}\right)$ & $A 3\left(F_{b}\right)$ & $A 4\left(F_{a b}\right)$ \\
\hline Azelnidipine & 16 & 16 & 16 & 16 \\
\hline $\mathrm{H} \beta C D$ & - & 31.6 & - & 31.2 \\
\hline Kolliphor HS15 & - & - & 6 & 6 \\
\hline Cross Carmellose Sodium & 10.5 & 10.5 & 10.5 & 10.5 \\
\hline PVP & 3.7 & 3.7 & 3.7 & 3.7 \\
\hline Talc & 3.7 & 3.7 & 3.7 & 3.7 \\
\hline Magnesium stearate & 3.7 & 3.7 & 3.7 & 3.7 \\
\hline Lactose & 38.7 & 7.1 & 31.7 & 1.5 \\
\hline Total weight (mg) & 76.3 & 76.3 & 76.3 & 76.3 \\
\hline
\end{tabular}

Table 3: Hardness, Friability, Disintegration Time and Drug Content of Azelnidipine Tablets Formulated employing $\beta C D$ and Kolliphor HS15

\begin{tabular}{|c|c|c|c|c|}
\hline $\begin{array}{c}\text { Formulation(code as per } \\
\mathbf{2}^{2} \text {-Factorial Design) }\end{array}$ & Hardness(kg/sq.cm) & Friability (\%) & $\begin{array}{c}\text { Disintegration Time } \\
\text { (min.) }\end{array}$ & $\begin{array}{c}\text { Azelnidipine } \\
\text { content (Percent) }\end{array}$ \\
\hline A1(1) & 7.2 & 0.51 & 3.2 & 99.6 \\
\hline A2(a) & 6.7 & 0.60 & 1.8 & 94.6 \\
\hline A3(b) & 6.1 & 0.42 & 1.2 & 99.7 \\
\hline A4(ab) & 7.1 & 0.77 & 0.8 & 98.5 \\
\hline
\end{tabular}


Table 4: Hardness, Friability, Disintegration Time and Drug Content of Azelnidipine Tablets Formulated employing HP $\beta C D$ and KolliphorHS15

\begin{tabular}{|c|c|c|c|c|}
\hline $\begin{array}{c}\text { Formulation(code as per } \mathbf{2}^{\mathbf{2}} \\
\text {-Factorial Design) }\end{array}$ & Hardness(kg/sq.cm) & Friability (\%) & $\begin{array}{c}\text { Disintegration Time } \\
\text { (min.) }\end{array}$ & $\begin{array}{c}\text { Azelnidipine } \\
\text { content (Percent) }\end{array}$ \\
\hline A5(1) & 7.1 & 0.81 & 3.5 & 99.9 \\
\hline A6(a) & 7.4 & 0.68 & 2.4 & 95.4 \\
\hline A7(b) & 6.3 & 0.52 & 1.7 & 98.5 \\
\hline A8(ab) & 7.2 & 0.47 & 1.9 & 94.3 \\
\hline
\end{tabular}

Table 5: Dissolution Profiles of Azelnidipine Tablets Formulated Employing $\beta C D$ and Kolliphor HS15as Per $2^{2}$ Factorial Design

\begin{tabular}{|c|c|c|c|c|}
\hline \multirow{2}{*}{ Time min } & \multicolumn{4}{|c|}{ Percent Azelnidipine dissolved ( ${ }^{-} x \pm s d$ ) } \\
\hline & & $A 2(a)$ & $A 3(b)$ & $A 4(a b)$ \\
\hline 5 & $4.22 \pm 0.763$ & $13.60 \pm 0.783$ & $17.85 \pm 0.660$ & $26.65 \pm 1.55$ \\
\hline 10 & $6.32 \pm 0.427$ & $16.77 \pm 0.303$ & $27.05 \pm 0.519$ & $35.05 \pm 0.465$ \\
\hline 15 & $7.80 \pm 0.424$ & $23.32 \pm 0.780$ & $35.35 \pm 0.785$ & $46.15 \pm 0.55$ \\
\hline 20 & $9.40 \pm 0.673$ & $29.27 \pm 0.780$ & $42.25 \pm 0.465$ & $56.35 \pm 0.613$ \\
\hline 30 & $11.30 \pm 0.912$ & $35.07 \pm 0.607$ & $47.05 \pm 0.723$ & $67.60 \pm 0.588$ \\
\hline 40 & $12.57 \pm 0.531$ & $42.92 \pm 1.28$ & $51.27 \pm 0.788$ & $82.60 \pm 1.641$ \\
\hline 50 & $14.62 \pm 1.078$ & $44.32 \pm 0.921$ & $54.50 \pm 1.35$ & $86.90 \pm 1.248$ \\
\hline 60 & $15.65 \pm 0.866$ & $46.87 \pm 0.75$ & $56.82 \pm 0.44$ & $93.12 \pm 2.203$ \\
\hline
\end{tabular}

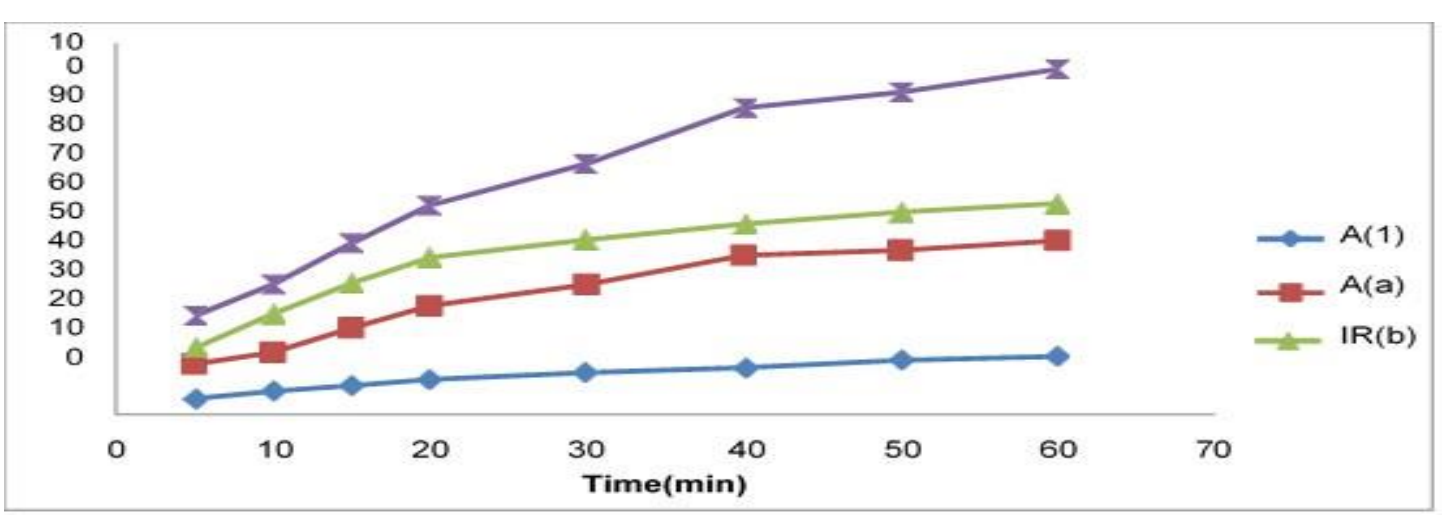

Figure 1: Dissolution Profiles of Azelnidipine tablets formulated employing $\beta C D$ and Kolliphor HS15 as per $2^{2}$ Factorial Design

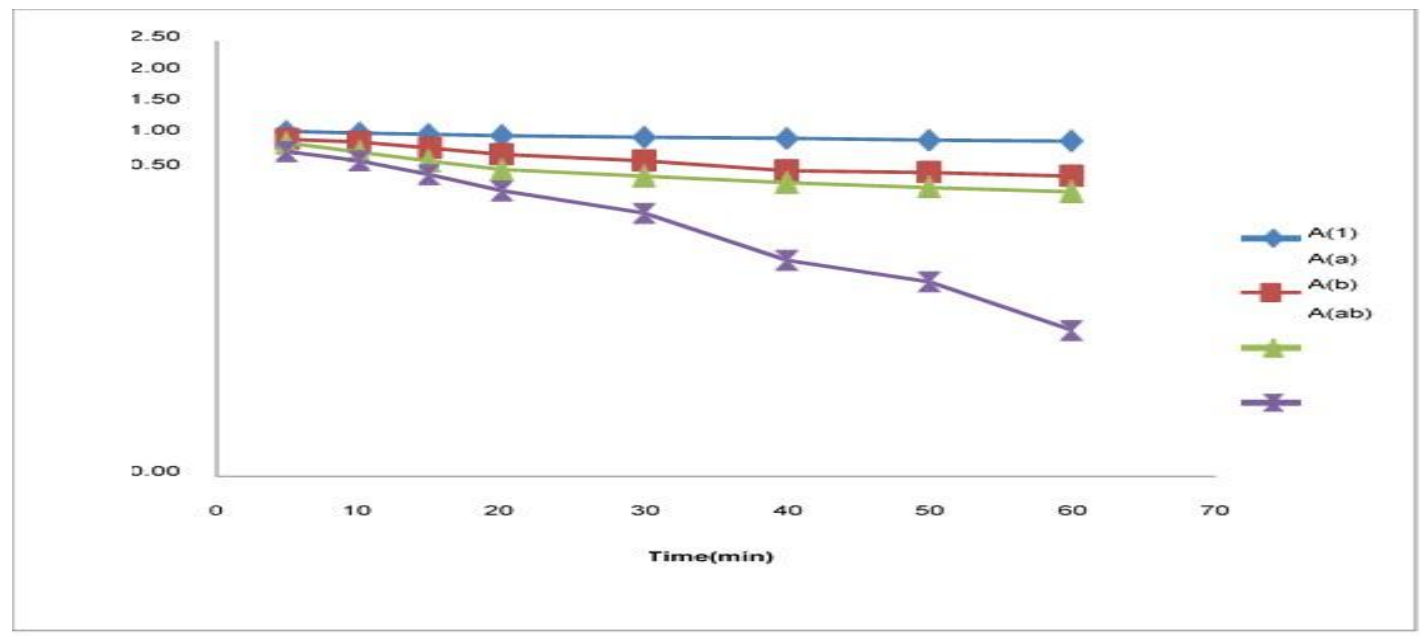

Figure 2: First Order Dissolution Profiles of Azelnidipine tablets formulated employing $\beta C D$ and Kolliphor HS15 as per $2^{2}$ Factorial Design 
Table 6: Dissolution Profiles of Azelnidipine Tablets Formulated Employing HPßCD and Kolliphor HS15as Per $2^{2}$ Factorial Design

\begin{tabular}{|c|c|c|c|c|}
\hline \multirow{2}{*}{$\begin{array}{l}\text { Time } \\
\text { (min) }\end{array}$} & \multicolumn{4}{|c|}{ Percent Azelnidipine Dissolved ( $x \pm s d$ ) } \\
\hline & $\operatorname{Ir5}(1)$ & $\operatorname{Ir6}(\mathrm{a})$ & $\operatorname{Ir7}$ (b) & Ir8(ab) \\
\hline 5 & $4.22 \pm 0.763$ & $15.02 \pm 0.623$ & $17.85 \pm 0.660$ & $21.3 \pm 0.808$ \\
\hline 10 & $6.32 \pm 0.427$ & $18.85 \pm 0.479$ & $27.05 \pm 0.519$ & $30.25 \pm 0.619$ \\
\hline 15 & $7.80 \pm 0.424$ & $21.9 \pm 1.122$ & $35.35 \pm 0.785$ & $40.92 \pm 1.335$ \\
\hline 20 & $9.40 \pm 0.673$ & $28.22 \pm 0.967$ & $42.25 \pm 0.465$ & $52.92 \pm 2.168$ \\
\hline 30 & $11.3 \pm 0.912$ & $34.80 \pm 0.637$ & $47.05 \pm 0.723$ & $64.47 \pm 1.386$ \\
\hline 40 & $12.57 \pm 0.531$ & $42.92 \pm 0.525$ & $51.27 \pm 0.788$ & $76.42 \pm 4.598$ \\
\hline 50 & $14.62 \pm 1.078$ & $45.30 \pm 0.883$ & $54.50 \pm 1.35$ & $82.27 \pm 2.725$ \\
\hline 60 & $15.65 \pm 0.866$ & $46.87 \pm 0.809$ & $56.82 \pm 0.44$ & $86.92 \pm 1.284$ \\
\hline
\end{tabular}

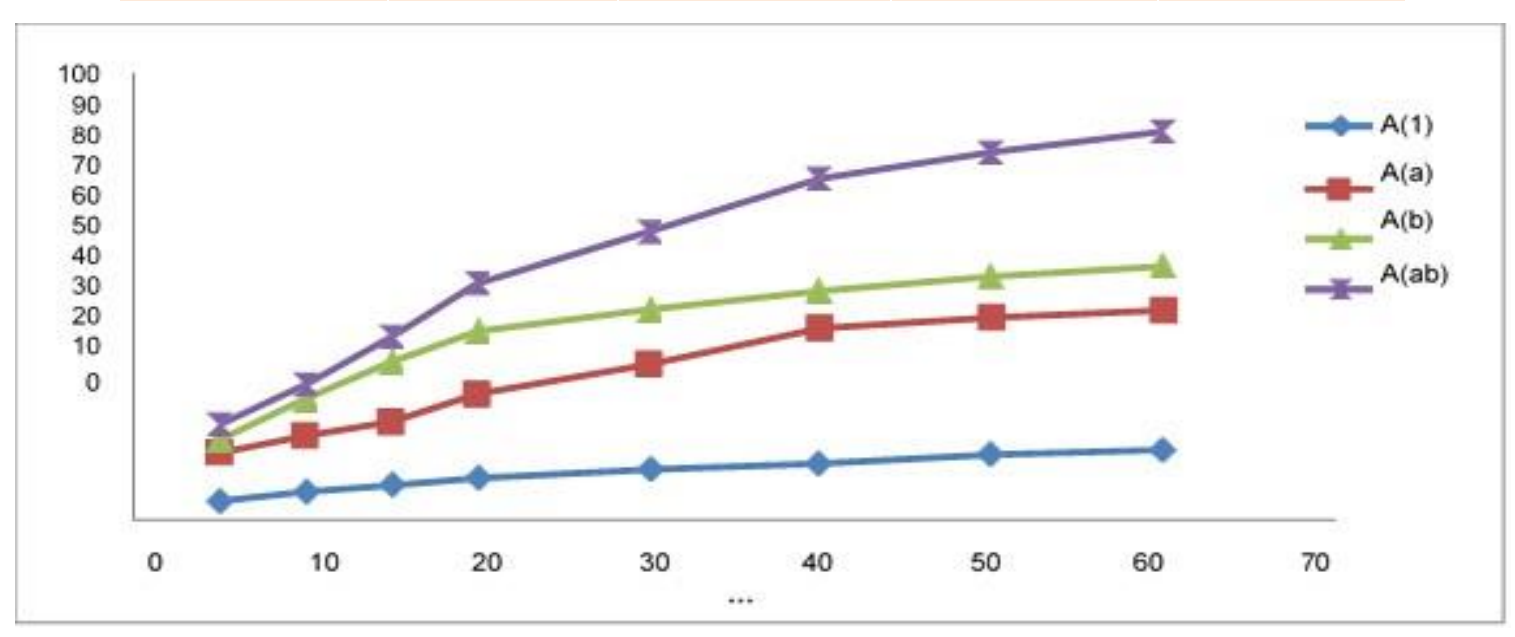

Figure 3: Dissolution Profiles of Azelnidipine tablets formulated employing HPßCD and Kolliphor HS15 as per $2^{2}$ Factorial Design

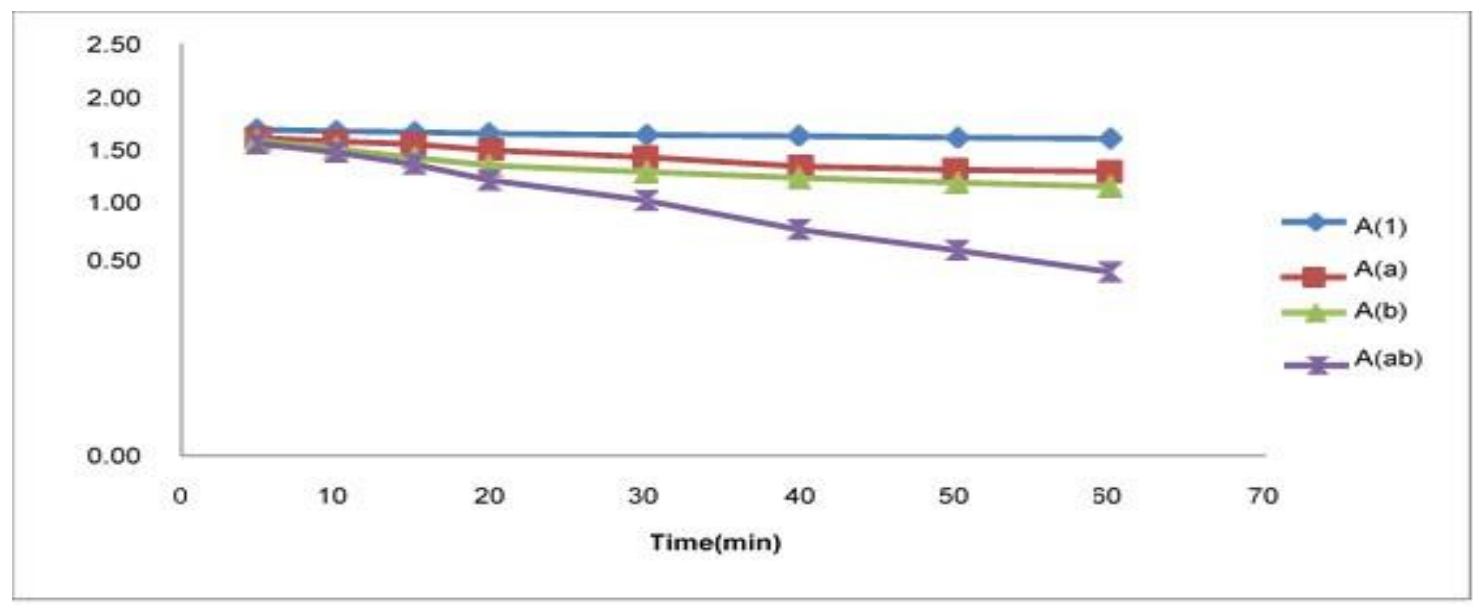

Figure 4: First Order Dissolution Profiles of Azelnidipine tablets formulated employing $\beta C D$ and Kolliphor HS15 as per $2^{2}$ Factorial Design

\section{Results and discussion}

The post compression parameters such as hardness, friability, thickness, disintegration time, and drug content are shown in Table 3 and Table 4 . In all the formulations, the hardness test indicates good mechanical strength. Friability of all formulations was less than $1 \%$, which indicated that the tablets had a good mechanical resistance. Drug content was found to be high ( $\geq 101.00 \%$ ) and uniform in all the formulations. The important parameter that requires to be optimized in the development of the fast-disintegrating tablets is the disintegration time of the tablets. In the present investigation, all the tablets disintegrated in $\leq 100$ seconds fulfilling the official requirements ( $<3$ min.) for disintegrating tablets ${ }^{10}$. The absorption of water is an important step for the subsequent disintegration process 
of tablets ${ }^{11}$. Bi et. al. ${ }^{12}$ have reported that when higher concentration of super disintegrants were added to the tablet formulation, they absorbed considerable amount of water and resulted in increase in viscosity of fluid within the tablet mass. This delayed further water penetration into the tablets. Therefore, it was decided to use super disintegrants concentrations only up to $5 \% \mathrm{w} / \mathrm{w}$.

Drug-CD and Drug-CD-Kolliphor HS15complex systems could be formulated into compressed tablets by wet granulation method. The hardness, friability, drug content and disintegration time of the tablets prepared are given in Tables 3,4. Hardness of the tablets was in the range 6.0 $-7.5 \mathrm{~kg} / \mathrm{sq} . \mathrm{cm}$. Percent weight loss in the friability test was less than $0.85 \%$ with all the formulations. The disintegration time was in the range $1-3.5 \mathrm{~min}$. with all the tablets prepared. Drug content of the tablets was within $100 \pm 2 \%$ of the labeled claim.

\section{Dissolution Rate Characteristics of Azelnidipine Tablets}

Dissolution of Azelnidipine from all the prepared tablets was studied in $0.1 \mathrm{~N}$ hydrochloric acid. The dissolution profiles of the Azelnidipine tablets prepared are given in Table 7.23-7.24 and in Fig. 7.5-7.8. Dissolution data were analyzed as per zero and first order kinetics. The coefficient of Determination $\left(R^{2}\right)$ values in the analysis of dissolution data indicated that the dissolution of Azelnidipine from all the tablets formulated followed first order kinetics. The coefficient of Determination $\left(R^{2}\right)$ values were in the range 0.8927-0.9978 with all the Azelnidipine tablets prepared. The first order dissolution plots are shown in Figs. 2 and 4 . The first order dissolution rate $\left(K_{1}\right)$ values along with dissolution efficiency $\left(D_{30}\right)$ values of various Azelnidipine tablets prepared .Tablets formulated employing CDs and Kolliphor HS15 gave relatively higher rates $\left(K_{1}\right)$ of dissolution and dissolution efficiency ( $D_{30}$ ) values when compared to the Azelnidipine plain tablets (i.e. tablets formulated with Azelnidipine alone ). The order of increasing dissolution rate $\left(K_{1}\right)$ observed with various Azelnidipine tablets was $A 1$ ( plain ) $<A 2(B C D)=A 6$ $(\mathrm{HPBCD})<\mathrm{Ar3}$ (Kolliphor HS15) < A8 ( HP BCD-Kolliphor HS15 ) <A4 ( $\beta C D-K o l l i p h o r ~ H S 15)$ Formulations A4 and A8, which are formulated employing $\beta C D$-Kolliphor HS15 and HP $\beta C D-K o l l i p h o r$ HS15 respectively, gave much higher dissolution rates when compared to plain tablets, A1. A 21.35 and 16.85 fold increase in $K_{1}$ was observed respectively with formulations $A 4$ and $A 8$ when compared to formulation $A 1$ (plain tablets). The dissolution efficiency ( $D_{30}$ ) was also increased from $7.29 \%$ for Formulation $A 1$ (plain tablets) to $43.32 \%$ and $39.36 \%$ respectively for formulations $\mathrm{A} 4$ and $\mathrm{A} 8$.

\section{REFERENCES}

1. Omidian H, Park K. Oral targeted drug delivery systems: gastric retention devices. In: Wen $\mathrm{H}$, Park K, editors. Oral controlled release formulation design and drug delivery: Theory to practice. New Jersey: Wiley; 2010; pp. 185-204.

2. Davis SS. Formulation strategies for absorption windows. Drug Discov Today. 2005; 10(4): 249-257.

3. Hoffman A, Stepensky D, Lavy E, Eyal S, Klausner E, Friedman M. Pharmacokinetic and pharmacodynamic aspects of gastroretentive dosage forms. Int J Pharm. 2004; 277: 141153.

4. Oizumi K, Nishino $H$, Koike $H$, Sada $T$, Miyamoto $M$, Kimura $\mathrm{T}$ : Antihypertensive effects of CS-905, a novel dihydropyridine Ca++ channel blocker. Jpn J Pharmacol. 1989; 51(1): 57-64.

5. Nada T, Nomura M, Koshiba K, Kawano T, Mikawa J, Ito S: Clinical study with azelnidipine in patients with essential hypertension. Antiarteriosclerotic and cardiac hypertrophyinhibitory effects and influence on autonomic nervous activity. Arzneimittel for schung. 2007; 57(11): 698-704.

6. Patel DM, Patel DJ, Shah SK and Shah AS. Formulation and evaluation of fast dissolving tablets of nebivolol and valsartan. International journal of pharmaceutical sciences and research,2020; 11(11): 5530-39.

7. Rabab A.Husseinymr S.Abu Lila, Marwa H.Abdallah, Hanaa A.El-ghamry. Fast disintegrating tablet of Valsartan for the treatment of pediatric hypertension: In vitro and in vivo evaluation. Journal of drug delivery science and technology.2018; 43: 194-200.

8. 8. Meghawati R. Badwar, Sandhya L. Borse, Manish S. Junagade, Anil G. Jadhav. Formulation and evaluation of mouth dissolving tablet of amlodipine besylate. International journal of applied pharmaceutics. 2019; 11(4): 23-27.

9. 9. Lalji V Amipara, M M Gupta. Oral disintegrating tablet of antihypertensive drug. Journal of Drug Delivery \& Therapeutics; 2013; 3(1): 85-92.

10. 10.European department for the quality of medicines. In: European Pharmacopoeia. 3rded. Strasbourg: Supplement; 2001; 1666-9.

11. 11.Deshmukh Sambhaji S, Potnis Vaishali V, Mahaparle Paresh R, Kasture Pramod V and Ghare Vikram S: Development of Evaluation of Ziprasidone Hydrochloride Fast Disintegrating/ Dissolving Tablets using Complexation Techniques. Indian J. Pharm. Educ. 2009;3: 43.

12. 12.Bi YX, Sunada $\mathrm{H}$, Yonezawa $\mathrm{Y}$ : Evaluation of rapidly disintegrating tablets prepared by direct compression method. Drug Dev Ind Pharm. 1999; 25: 571-581.

Source of Support: The author(s) received no financial support for the research, authorship, and/or publication of this article.

Conflict of Interest: The author(s) declared no potential conflicts of interest with respect to the research, authorship, and/or publication of this article.

For any question relates to this article, please reach us at: editor@globalresearchonline.net

New manuscripts for publication can be submitted at: submit@globalresearchonline.net and submit_ijpsrr@rediffmail.com 